\title{
Efficiency of brazilian food and beverage industry post productive restructuring
}

\author{
Dênis Antônio da Cunha ${ }^{1}$ \\ Marlon Bruno Salazar ${ }^{2}$
}

\begin{abstract}
This paper aims to analyze the technical efficiency of the Brazilian food and beverage industry post productive restructuring, under the hypothesis that foreign firms would be more efficient than the Brazilian ones. The analytical framework for efficiency was Data Envelopment Analysis (DEA) and Tobit model. DEA only measures the "relative" technical efficiency; that is to say that there is evidence of huge variance in technical efficiency, but we cannot conclude that the absolute level of efficiency is low. It was observed that the companies with high efficiency levels were those with the highest volume of sales. Thus, efficiency was not determined only by the nationality of the firms, since the possibility of the accomplishment of profitable businesses, mainly in association with great retail networks, could be indicated as a determinant for greater efficiency. As for the determinants of efficiency, it was observed that a proper financial administration, characterized by a good use of investments within these companies, was the main factor responsible for an improvement in performance.
\end{abstract}

Keywords: Brazilian Food and Beverage Industry, Efficiency, DEA, Tobit.

JEL: D22

\section{Eficiência da Indústria de Alimentos e Bebidas Brasileira Pós Reestruturação Produtiva}

Resumo: O objetivo deste estudo foi analisar a eficiência técnica da indústria de alimentos e bebidas brasileira, sob a hipótese de que as firmas estrangeiras seriam mais eficientes. O referencial analítico foi baseado na Análise Envoltória de Dados e no modelo Tobit. Como a DEA mede a eficiência técnica "relativa", pôde-se

1 Doutor em Economia Aplicada. Prof. Adjunto do Departamento de Economia Rural da Universidade Federal de Viçosa (UFV). E-mail: denisufv@gmail.com

2 Doutor em Economia Aplicada. Analista em Informações Geográficas e Estatísticas do Instituto Brasileiro de Geografia e Estatística (IBGE). E-mail: marlonbrunosalazar@yahoo.com.br 
concluir que há provas de variância enorme na eficiência técnica, mas não se pôde afirmar que o nível absoluto de eficiência é baixo. Observou-se que empresas com elevados níveis de eficiência foram aquelas com o maior volume de vendas. Assim, a eficiência não foi determinada apenas pela nacionalidade das empresas, já que a possibilidade da realização de negócios lucrativos, principalmente em associação com grandes redes de varejo, pode ser indicada como fator determinante para a maior eficiência. Quanto aos determinantes da eficiência, observou-se que uma boa administração financeira, caracterizada por um bom uso de investimentos, foi o principal fator responsável por uma melhoria no desempenho.

Palavras-Chave: Indústria Brasileira de Alimentos e Bebidas, Eficiência, DEA, Tobit.

JEL: D22

\section{Introduction}

Since the 1990s, the Brazilian government has intensified the process of commercial liberation, utilizing, as one of the main instruments, a significant reduction in the import tariffs of several products in the transformation of industry. In relative terms, the major reductions occurred within the sectors of consumption goods (Barreto et al., 2006).

The immediate consequence of this process has been the exposure of internal production to the international dynamics of supply and demand. For consumers, this has meant a bigger range of products with lower prices; in some sectors of the economy, however, the effects have had an adverse consequence, resulting in bankruptcies and an increase in unemployment and other less formal jobs.

In particular, the food and beverage industry moved through significant changes, whereby the average tariffs were reduced, respectively, from $77.5 \%$ and $159,5 \%$ in the period of $1985 / 89$ to $12.5 \%$ and $13,9 \%$ in $1994 / 95^{1}$.

The sector started a productive and business restructuring, whose most prominent manifestation was the process of mergers and, or, acquisitions (M\&A). From 1992 to 2004, the food sector had a total of 424 M\&A's, which represents $11 \%$ of the total for all sectors. According to Farina and Viegas (2005), many of these transactions took place with the participation of foreign capital, when foreign companies purchased the control of local companies or had joint ventures to create a third company.

This led to greater Foreign Direct Investment (FDI) inflow, a development of activities with greater aggregate value, easier access for the country to the

1 The food and beverage sectors are considered a unique industry, but they face different tariffs. The data of reduction of taxes were firstly presented in Barreto et al. (2006). 
foreign markets and greater dynamism in the domestic market. At present, some important multinational companies within the segment are developing activities in Brazil.

The process of trade liberalization and new patterns of competition have resulted in a need for modernization, with an improvement in products and greater productivity and organizational efficiency, in view of external competition. Small companies, which form the absolute majority in this sector, have had great difficulty in adapting, and, at the same time, their possibilities for being competitive have become smaller over time.

Beyond the commercial entrance, the economy passed through a period of price stabilization in the 1990 . The reduction of inflation, from 1994 onwards, represented a gain in terms of real income for a great proportion of the population. This fact also led to further implications in the sector of food and beverage, increasing, significantly and permanently, the demand of its products (especially those of greater aggregate value), which, during that time, was an important motivator for new investments.

The business restructuring is also related to consumers. For Farina and Viegas (2005), multinational companies were attracted, mainly, by an expansion in the market and in the consumption of more value added products. The market has now required more quality and comfort, which increases the competition between firms. The result is that business strategies of development and improvement of products take into account, increasingly, the segmentation of the consumer markets and attempt to focus on an improved service to them.

The implication of these changes has been due to the concentration within the market. According to estimates produced by Cunha and Dias (2008), in 1990 , the fourth and eighth biggest companies in the sector presented respectively, $31.62 \%$ and $44.32 \%$ of the total market sales; in 2004, the leading firms controlled $39.91 \%$ and $54.32 \%$ of the total market sales.

It is now necessary to verify the efficiency of the sector with regards to all the changes it has moved through, and to identify whether there are differences between national and foreign companies (some of the foreign companies that established themselves in the country, during recent years and during the changes described previously).

Studies on efficiency have increased in Brazil within the decade of 1990, especially because of the changes in the industrial structure that occurred following the Brazilian trade liberalization. However, there are not many studies that deal with the food and beverage industry. Macedo and Souza (2004), studying the organizational efficiency of the sector, limited themselves to the seven biggest firms, with the objective of only evaluating whether the employed methodology would be able to serve as a parameter in the administrative process of decision-making. With respect to the foreign capital in the 
sector, Farina and Viegas (2005) analyzed the multinational companies and through their study focused on the reasons of their entrance and the impacts on the structure of the industry, without a formal study on efficiency and, or, a comparison among companies.

Therefore, the main objective of this work was to analyze the efficiency of the Brazilian food and beverage industry, with a view to identifying whether there are differences between multinational and Brazilian companies. Specifically, to measure the estimated technical efficiency of the companies and verify some conditional factors of efficiency.

Besides this introduction, the article has four other sections. In the second section, there is a short exposition of the concept of efficiency; in the third section, the methodological procedures are described; in the fourth section, the results are presented and discussed; and the final section focuses on the main conclusions of the study.

\section{Efficiency}

Farrel (1957) initiated the argument regarding the measurement of efficiency in firms, stating that the efficiency of a firm was composed of two measures that are combined to obtain the total measurement of economic efficiency: i) technical efficiency, which is related to the ability of the company to obtain the maximum product from a set of inputs; and ii) allocated efficiency, which reflects the ability of the firm to utilize the inputs in an optimum proportion, given their relative prices. Therefore, an economically efficient productive process is the one that generates the highest profit through the lowest cost. To evaluate whether a process is efficient, it is necessary to compare it to an ideal situation, which could be obtained from the combinations of inputs and outputs.

Measurements of efficiency can be calculated by obtaining an efficient technology, which, in general, is represented by some kind of frontier function. A frontier of production defines the limits of maximum productivity that a resource can achieve in a process of transformation, according to a certain combination of inputs. Thus, a measure of inefficiency would be the distance that a unit of production is set below the production frontier ${ }^{2}$.

According to Caves (1992) and Mayes et al. (1994), who were cited by Fethi et al. (2002), the efficiency determinants can be analyzed under five main points

2 The evaluation of the technical efficiency, in the analysis by Farrel (1957), can be carried out by the input orientation, which is based on the reduction of inputs, and the output orientation, which stresses the increase of output. 
of view: i) the absence of competition is a cause of inefficiency, whether it is due to either the market concentration or to the absence of trade liberalization; ii) managerial and organizational aspects can influence the activities of a firm; iii) a heterogeneous structure among companies can cause different standards of efficiency; iv) dynamic factors, such as R\&D, innovations and market growth, help to maintain efficiency; v) Public Policies can create incentives for the improvement of efficiency.

\section{Methodology}

Initially, the Data Envelopment Analysis (DEA) was used to measure the scores of technical efficiency; subsequently, the bootstrap method was employed to compare the averages of efficiency between foreign and national companies. Finally, a Tobit econometric model was used to identify estimated determinants of efficiency.

\subsection{The methodologies for efficiency measurement}

The DEA is a non-parametric approach of mathematical programming, which was developed by Charnes et al. (1978), on the basis of the analyses of efficiency proposed by Farrel (1957). The technique is based on a sample of observed inputs and outputs of different firms, or decision making units (DMU's). It aims to construct a convex set of references, obtained from the data, and then classify the DMU's as either efficient or inefficient, which will be used as a referential standard.

To measure the efficiency of a company, its levels of inputs and outputs are compared with the possible levels found in the reference set. A DMU will be efficient when no other firm, or combination of firms, within the reference set, produces better products with the same inputs or presents a quality inferior to theirs.

The two classic models of DEA, which were developed respectively by Charnes et al. (1978) and Banker et al. (1984), are: CCR, which assumes constant returns to scale, and BCC, which assumes variable returns. In this study, the two models were used under the input orientation, i.e. the amount of inputs was minimized, without altering the amount of output. In the following, the two formularizations described use Coelli et al. (1998) as a reference.

The CCR model consists of the following problem of duality in linear programming: 
$\operatorname{MIN}_{\theta, \lambda} \theta$, subject $\quad 0:-y_{i}+Y \lambda \geq 0, \quad \theta x_{i}-X \lambda \geq 0$ and $\lambda \geq 0$ (1)

where $\theta$ is a scale that represents the degrees of efficiency in i-th DMU; a firm will be efficient when $\theta=1$ and inefficient when $\theta<1$. The parameter $\lambda$ is a vector $(n \times 1)$, and its values are calculated to obtain the optimal solution; efficient DMUs will have $\lambda=0$ and, for the inefficient ones, the values of $\lambda$ will be the weights used in the combination of the other efficient DMUs, which influenced the projection of the inefficient DMU on the calculated frontier; $y_{i}$ and $x_{i}$ are vectors, respectively, of the amount of outputs ( $m x$ 1) and inputs $\left(\begin{array}{lll}k & \times 1\end{array}\right)$ of the $i$-th DMU; $Y$ is the matrix of outputs $(n \times m)$ and, of inputs $(n \times k)$. Since it is necessary to obtain a value for $\theta$ in every DMU, the problem has to be solved $N$ times.

However, when the DMU's are not all operating within a good scale, the use of the CCR model produces a result in measures of technical efficiency that could be confused with scale efficiency. Therefore, the problem of linear programming with constant returns can be modified, to include an assumption for changeable returns (BCC model) which then calculate the technical efficiencies free of any scale factors. The change is carried out by a restrictive addition to the convexity of the problem:

$\operatorname{MIN}_{\theta, \lambda} \theta$, subject $\quad b:-y_{i}+Y \lambda \geq 0, \theta x_{i}-X \lambda \geq 0, N_{1}{ }^{\prime} \lambda=1$ and $\lambda \geq 0$ (2)

where $N_{1}$ is a vector ( $\mathrm{N} \times 1$ ) of unitary numbers (algorithms).

If a DMU is efficient in the CCR model, it will also be in the BCC, for the measure of technical efficiency within the former, and will be composed by the technical efficiency of the latter and by the measure of the scale of efficiency. Therefore, it implies that if a DMU has a technical efficiency score that is different in the two models it will possess scale inefficiency. The efficiency/ inefficiency of a scale is calculated by the ratio between the scores of the CCR and BCC models.

Although the DEA is frequently used, a great number of researchers ignore the effects of the error on the efficiency estimation. According to Dong and Featherstone (2006), the traditional uses of DEA have either been ignored or only superficially argued regarding the issue of uncertainty associated with its estimates. Many works have pointed out the necessity to verify these results, including Efron and Tibshirani (1993), Lothgren and Tambour (1999) and Souza and Tabak (2002).

To avoid this problem, the bootstrap statistical technique has been applied, using the available set of data to proceed an experiment in which the data themselves are used to create artificial samples, by means of a procedure of 
random resampling, therefore being a principle of substitution, hence relative frequency.

According to Simar and Wilson (1997), the bootstrap is currently the main instrument used to investigate the confidence in the estimators of scores of efficiency, for attributing a degree of confidence from within a certain level of probability. The algorithm of the bootstrap procedure allows various resamplings to take place, derived from multiple iterations carried out by computational procedures that act on the scores obtained by the DEA, allowing the calculated average to be either validated or refused, a priori, by the constructed confidence intervals ${ }^{3}$.

The average levels of efficiency obtained by the DEA are values that vary from o to 1, which makes it impracticable to use an Ordinary Least Squares method (OLS). Thus, many authors have estimated a regression, of the Tobit type, to verify the determinants of efficiency. Chilingerian (1995), Bravo-Ureda and Pinheiro (1997), Jackson and Fethi (2000), and Hoff (2007) also present similar works.

The econometric Tobit model is used in when the dependent variable is amongst the ranges of values, or concentrated on points that are equal to a limit-value. With the proper use of the statistical terms, there is, in these cases, what is called a censored sample. Thus, the model aims to avoid the problem of censoring through statistical techniques that allow possible inferences on all the population without loss of quality.

According to Greene (1993), it is possible to define this model by the following index function:

$$
y_{i}^{*}=X_{i} \beta+\mu_{i}
$$

where $y_{i}^{*}$ is the index variable; $X_{i}$, the vector of explanatory variables; $\beta$, the vector of the parameters to be estimated; and $u_{i}$, the random error, which is usually distributed about the zero average and constant variance. The value of the "censoring" is denoted by $y^{c}$. Thus, what is observed in the sample is $y_{i}=y_{i}^{*}, f \quad y_{i}^{*}<y^{c}$ and $y_{i}=y_{i}^{c}, f \quad y_{i}^{*} \geq y^{c}$.

In this case, the most adequate option to build consistent estimators is to estimate the parameters $\beta$ 's of the model by means of the method of maximum likelihood. Moving this way, it becomes possible to isolate and describe the contribution of the censored variables, for the formation of the likelihood function. 
Contribution of the censored variables:

$$
\begin{aligned}
\operatorname{Pr}\left(y i=y^{c}\right) & =\operatorname{Pr}\left(y_{i}^{c} \geq y^{c}\right) \\
& =\operatorname{Pr}\left(X_{i} \beta+u i \geq y^{c}\right)=\operatorname{Pr}\left(u i \geq y^{c}-X_{i} \beta\right) \\
& =\operatorname{Pr}\left(\frac{u i}{\sigma} \geq \frac{y^{c}-X_{i} \beta}{\sigma}\right)=1-\operatorname{Pr}\left(\frac{u i}{\sigma} \leq \frac{y^{c}-X_{i} \beta}{\sigma}\right)=1-\phi\left(\frac{y^{c}-X_{i} \beta}{\sigma}\right)
\end{aligned}
$$

Contribution of the non-censored variables:

$$
\begin{aligned}
\operatorname{Pr}\left(y i=y_{i}^{*}\right) & =\operatorname{Pr}(y i=X i \beta+u i) \\
& =\operatorname{Pr}\left(u i=y_{i}-X i \beta\right) \\
& =\operatorname{Pr}\left(\frac{u i}{\sigma}=\frac{y i-X i \beta}{\sigma}\right)=\frac{1}{\sigma} \varphi\left(\frac{y i-X i \beta}{\sigma}\right)
\end{aligned}
$$

With these two components, it is then possible to formulate the log-likelihood function of the Tobit model, in order to find the estimated values for the vector of parameters $\beta$ and for the parameter $\sigma$ of the standard error of the regression:

$$
l(\beta, \sigma, y)=\sum_{j \geq y_{i}^{c}} \log \left[1-\phi\left(\frac{y_{i}^{c}-X_{i} \beta}{\sigma}\right)\right]+\sum_{y_{i}=y_{i}^{c}} \log \left[\frac{1}{\sigma} \varphi\left(\frac{y_{i}-X_{i} \beta}{\sigma}\right)\right]
$$

where $\phi($.$) represents the function of the standard normal cumulative dis-$ tribution and $\varphi($.$) , the function of standard normal density.$

According to Greene (1993), the marginal effect, which measures the impact of each variable on the probability of the DMU to be efficient, is not obtained by the direct interpretation of the coefficients of the model, but by the application of the equation:

$$
M E_{x_{j}}=\frac{\partial E\left(y_{i}\right)}{\partial x_{j}}=\beta_{j} \Phi\left(\frac{x_{i} \beta}{\sigma}\right)
$$

where $\beta$ and $\sigma$ are the parameters estimated by the model.

To evaluate the global significance of the regression, the likelihood-ratio test (LR statistic) is used: 


$$
L R=2(U R F-R L F)
$$

where $U L F$ is the unrestricted log-likelihood function, which is obtained from the estimated model; and $R L F$, the restricted log-likelihood function, which results in the estimation of the model only with an intercept (considering that the other variables are equal to zero). The LR statistic follows the distribution $\chi^{2}$, with $m$ degrees of freedom ( $m$ refers to the number of explicative variables). The interpretation of the test is similar to the $F$ test, in the OLS models.

\subsection{Data}

The data used here were obtained from the Associação Brasileira das Indústrias da Alimentação (ABIA, 2007) and from the Revista Exame - Maiores $e$ Melhores, and refers to the year 2005. This year was analyzed due to the non-availability of data for samples of firms that effectively characterized the industry in the previous years.

Information about 85 companies was obtained, whose sales value varied from US $\$ 5,935.90$ to US $\$ 48,50$ million, and together represented approximately $70 \%$ of the sales of the sector. The sample includes firms operating in different sub-sectors of the industry (dairy products, meats and derivatives, processing of fruits, cereals and vegetables, alcoholic and non-alcoholic beverages).

To determine the efficiency using the DEA, the value of sales and the EBITDA (Earning Before Interest, Taxes, Depreciation and Amortization) were considered as outputs and both were expressed in dollars (millions); the number of employees and the equity were used as inputs and also in dollars (millions).

The explicative variables included in the econometric model were wages, net income, immediately liquidity and asset turnover. The former two are quoted in dollars (millions) and the others are economic-financial indices, which are in accordance with the approach of efficiency related to organizational and management aspects, previously mentioned. A dummy variable was also included, which had the value 1 (one), for companies whose shareholding control is foreign, and o (zero) for national firms. 


\section{Results and discussion}

\subsection{Technical efficiency}

In this section, the levels (scores) of technical and scale efficiency of each company within the sample are presented, which were obtained by CCR and BCC models with an input orientation. The DMU's that obtained scores equal or superior to 0,90 were considered efficient. The justification for this flexibility, which is widely found in literature, is that some DMU's can be more distinguished for being outliers and not due to the relative efficiency; in this sense, corruption of the analysis is avoided (Table 1).

The results of Table 1 show that, if the constant returns are considered, only five companies are technical efficient ( $6 \%$ of the sample); otherwise, following the hypothesis of variable returns, ten firms are efficient and the average of the technical efficiency goes up from 0,47 to 0,52 . The important piece of data is the difference between the averages (five percentile points), which refers to the scale of inefficiency. As for the technical inefficiency, $0,53(1-0,47)$ in the CCR model and $0,48(1-0,52)$ in the BCC model, indicate that the companies can reduce their inputs by $53 \%$ and $48 \%$, respectively, without compromising their level of production and sales.

TABLE 1 - TECHNICAL EFFICIENCY FOR THE SAMPLE OF COMPANIES OF THE BRAZILIAN FOOD AND BEVERAGE INDUSTRY, 2005

\begin{tabular}{lll}
\hline \multirow{2}{*}{ Efficiency Score } & Number of companies & \\
\cline { 2 - 3 } CCR model & BCC model \\
\hline $\mathrm{E}<\mathrm{O}, 4$ & 41 & 32 \\
$0,4 \leq \mathrm{E}<0,6$ & 19 & 23 \\
$0,6 \leq \mathrm{E}<0,7$ & 9 & 8 \\
$0,7 \leq \mathrm{E}<0,8$ & 6 & 7 \\
$0,8 \leq \mathrm{E}<0,9$ & 5 & 5 \\
$0,9 \leq \mathrm{E}<1, \mathrm{O}$ & 1 & 3 \\
$\mathrm{E}=1, \mathrm{O}$ & 4 & 7 \\
\hline Average & 0,47 & 0,52 \\
Minimum & 0,11 & 0,11 \\
Maximum & 1,00 & 1,00 \\
Standard Error & 0,24 & 0,25 \\
\hline
\end{tabular}

Source: Research Data.

It is necessary to emphasize that the results found in this study differ from those presented by Macedo and Souza (2004), who found an average value of $62,5 \%$ for the technical efficiency. The difference may well be due to the fact that the work used only seven companies and, except for the EBITDA variable, 
it used distinct inputs and outputs in relation to the ones used in this study.

The scores obtained for the scale efficiency indicated that only 21 companies were operating in an optimal scale (about $25 \%$ of the sample); it is therefore considered that these DMU's operated in the range of constant returns to the scale. Another problem of linear programming was formulated, which imposed the restriction of non-increasing returns, i.e., it was substituted, in the equation (2), the restriction $\left[N_{1}{ }^{\prime} \lambda-1\right]$ for $\left[N_{1}{ }^{\prime} \lambda \leq 1\right]$ ), to detect if the firms considered inefficient by this criterion had such results because they were operating with increasing or decreasing returns to scale ${ }^{5}$.

From the new imposed restriction, it was evident that, among the 64 companies that presented scale inefficiency, $45 \%$ operated with decreasing returns to scale and $55 \%$ with increasing returns. These firms could increase their technical efficiency by means of the reduction and/or increase of production, respectively.

By identifying the possible difference in the efficiency between national companies and those whose shareholding control is foreign, confidence intervals for the averages of technical efficiency were calculated, in the CCR and BCC models, using the bootstrap methodology (Table 2).

TABLE 2 - CONFIDENCE INTERVALS FOR THE AVERAGES OF TECHNICAL EFFICIENCY, CCR AND BCC MODELS

\begin{tabular}{lcccccc}
\hline Sharehol- & \multicolumn{2}{c}{ Average } & \multicolumn{3}{c}{ Confidence Interval } \\
\cline { 2 - 7 } $\begin{array}{l}\text { dingCon } \\
\text { trol }\end{array}$ & CCR & \multirow{2}{*}{ BCC } & \multicolumn{2}{c}{ CCR model } & \multicolumn{2}{c}{ BCC model } \\
\cline { 4 - 7 } & & & Minimum & Maximum & Minimum & Maximum \\
\hline National & 0,4486 & 0,4907 & 0,4068 & 0,4928 & 0,4452 & 0,5381 \\
Foreign & 0,5608 & 0,6588 & 0,4488 & 0,6857 & 0,5232 & 0,7912 \\
\hline
\end{tabular}

Source: Research Data.

* Interval calculated after a thousand of iterations, to $95 \%$ of probability.

It is emphasized, initially, that the average efficiency of the national companies was smaller than that of the foreign companies in both models. However, the confidence intervals, at $5 \%$ of significance, led to the rejection of the hypothesis that the DMU's of the Brazilian shareholding control companies are less efficient than their multinational competitors. This statement can be made, since the maximum limit of confidence interval, for the national firms, is bigger than the minimum of foreign companies, i.e., they are within their confidence intervals. It is also worth mentioning that the bootstrap indicated similar results when a smaller level of probability was considered (90\%).

4 The expression optimal scale used here does not refer, necessarily, to a minimum point of long-run average cost, but actually to constant returns to scale.

5 According to Coelli et al. (1998), a problem with the measurement of scale efficiency is that it does not indicate whether the DMU is operating in the range of increasing or decreasing returns; because of that, the condition of non-increasing returns (NIR) is imposed. If the result found for the techncial efficiency in the BCC model were equal to the NIR, there would be decreasing returns; if not, increasing returns. 
The results suggested here can be explained by some peculiarities of the studied sector. Although comprising about 40 thousand firms, the Brazilian food and beverage industry is rather concentrated and the biggest companies dominate more than half of the sales within the sector. Companies such as these are included in the sample of this study, together with others that, although representative when compared to the majority of the sector, are smaller than the leaders of the market. A low average efficiency can also be as a result of a delay in the technological modernization of some of these smaller firms.

The most efficient DMU's were those that produced goods of higher aggregate value (the most demanded in the current conjuncture of national food consumption $^{6}$ ) and with strong orientation for performing in the external market. Some of these companies are in all of the links of the agro food chain, which allows them to have a greater possibility for innovation of products and exploration of niche markets.

With concerns regarding the non-confirmation of the hypothesis that there is a difference in the efficiency between national companies and foreign shareholding control firms, the explanation may be found in the volume of sales. It is observed, in Table 3, that the leading firms in sales have an average score of efficiency that is significantly higher than that of other companies. According to Farina et al. (2005), the food and beverage sector's biggest companies were those with better conditions to divulge their products and to negotiate contracts for goods with retail networks. In Table 3, the group of firms with sales above a billion dollars comprises both companies with national capital, such as Sadia, Perdigão and Avipal, and multinational firms, such as Bunge, Cargill and Nestle.

TABLE 3 - AVERAGE EFFICIENCY ACCORDING TO THE VOLUME OF SALES, CCR AND BCC MODELS

\begin{tabular}{cccc}
\hline \multirow{2}{*}{ Volume of Sales* $^{*}$} & \multicolumn{2}{c}{ Model } & \multirow{2}{*}{ \% of the sample } \\
\cline { 2 - 3 } $\mathrm{S} \leq 1 \mathrm{CO}$ & 0.3393 & 0.4314 & $8 \%$ \\
$100<\mathrm{S}<1, \mathrm{OOO}$ & 0.4647 & 0.4909 & $81 \%$ \\
$\mathrm{~S} \geq 1, \mathrm{O00}$ & 0.5810 & 0.7830 & $11 \%$ \\
\hline
\end{tabular}

Source: Research Data.

* Sales in US\$ million.

Retail networks, the main place of sales of foods, have an important role in these results. According to a study conducted by the Fundação Getúlio Vargas (FGV, 2003), this segment also went through a process of concentration during the 1990s; the transformations in this sector have affected the relations with the suppliers, as with the food and beverage industry, given by the 
greater bargaining power of the retail sector. Thus, the biggest companies had the most suitable conditions to carry through contracts with large supermarkets, expanding their possibilities of sales and guaranteeing greater levels of efficiency.

\subsection{Determinants of Efficiency}

In the analysis of determinants of efficiency, the Tobit model was used, having as a dependent variable the efficiency scores obtained by means of the constant returns of a scale model, which were presented in the previous section. The reason for this choice was that the CCR model was considered to be more precise in the determination of efficiency, since, if a firm is to be considered efficient within constant returns, it must also be efficient in the model of variable returns (the opposite is not valid) (COELLI et al., 1998).

Table 4 shows the estimated parameters. The explicative variables, Wages (WA), Asset Turnover (AT), Immediately Liquidity (IL) and Net Income (NI), were individually significant at $1 \%$ and/or $5 \%$. The dummy variable (DU) was again included to test the hypothesis that the significance of foreign shareholding control companies would not be more efficient than the national ones. The model could be considered as globally significant at $1 \%$, since the calculated LR statistics (50.04) was greater than its critical value (15.09), which confirms that the estimated coefficients exert a joint influence on the dependent variable.

The variable wage exerted a very small negative impact on efficiency, since its marginal effect indicated a reduction of 0.00091 percentage point in each US $\$ 1$ million of increase in the expense of employees. It was therefore observed that the companies considered in this study would need to reduce their expenditures on employees to increase their efficiency, i.e., reduce the use of inputs.

The asset turnover was the variable that exerted the greatest positive impact on the efficiency. According to Assaf Neto (2006), this variable indicates the number of times that the total asset of a company was changed into money, as a result of the sales carried out within a certain period. The greater the turnover, the better the performance, indicating a more efficient use of the investments of the firms. According to the results, an increase of $10 \%$ in the asset turnover would increase the efficiency of the DMU by, approximately, 1.47 percentage point. 
TABLE 4 - FACTORS ASSOCIATED WITH THE TECHNICAL EFFICIENCY OF THE COMPANIES OF THE BRAZILIAN FOOD AND BEVERAGE INDUSTRY, 2005

\begin{tabular}{ccccc}
\hline Variables & Coefficients & Standard-Error & P-value & Marginal Effect \\
\hline Intercept & 0.263649 & 0.055438 & $0.00^{* * *}$ & 0.262437 \\
WA & -0.000909 & 0.000464 & $0.05^{* *}$ & -0.000905 \\
AT & 0.147543 & 0.022537 & $0.00^{* * *}$ & 0.146865 \\
IL & -0.033237 & 0.013733 & $0.02^{* *}$ & -0.033084 \\
NI & 0.000081 & 0.000034 & $0.02^{* *}$ & 0.000080 \\
DU & 0.019033 & 0.064354 & $0.77^{N S}$ & - \\
\hline
\end{tabular}

irrestricted log-likelihood function $=25.55$

restricted log-likelihood function (only with intercept)

$=0.53$

$\chi^{2}$ calculated $(\mathrm{LR})=50.04^{* * *}$

Source: Research Data.

$\left({ }^{* * *}\right),\left({ }^{* *}\right)$ and NS indicate, respectively, significant at $1 \%, 5 \%$ and non-significant.

The immediately liquidity generally indicates the capacity of payment within the short term of a company. The estimated parameter represented a negative value, suggesting that an increase of $10 \%$ in the current liquidity would reduce the efficiency by 0.33 percentage point. This result is to be expected, since in the literature of financial administration it involves a trade-off between security (higher liquidity, therefore greater capacity to finance the necessities of the working capital) and profitability; thus, the reduction in the liquidity could increase the economic efficiency and the use of resources to increase investments?

Within the microeconomic adjustments through which the food and beverage industry has passed during its productive and management restructuring, as argued by Farina and Nunes (2004), the reduction of the supplies of inputs and outputs must be emphasized. This change has resulted in the optimization of industrial processes and improvements in the logistics of distribution and supply. According to these authors, it had direct impact on the necessity of financing (working capital) of the companies. Such comment could also justify the results obtained for the changeable immediately liquidity.

The result for the net income variable indicated a small positive impact on the efficiency (0.00008 percentage point for each USS 1 million of increase in the revenue). Considering that this variable is obtained from the difference between the value of sales and the taxes placed on them, the issue regarding taxation becomes important in this analysis. The Brazilian tax burden is extremely high, which can compromise the efficiency of firms. The impact on the 7 Once it was not an objective of this study to discuss the aspects of the financial health of the companies, other details of this subject can be obtained in Assaf Neto (2006). The result for the current liquidity must be taken, therefore, with caution. 
net income could be greater with tax reduction. Finally, in what is regarded as the dummy variable, the result of the Tobit econometrical model confirmed the result obtained by the bootstrap methodology, which was discussed in the previous section. Competition became stronger with the entrance of multinational companies in the food and beverage industry; therefore, the concern regarding efficiency increased. However, organizational innovations and changes have also been observed in the national industries, without restricting themselves to the foreign firms, which a superficial analysis of the sector would clearly suggest.

\section{Final Considerations}

With trade liberalization, Brazilian industries found themselves in a new situation, facing difficulties, mainly due to competition with possibly more efficient foreign companies. This measure led to increased competition in the domestic market and a higher degree of concentration in some sectors. In this regard, the food and beverage industry had prominence. With an increased entrance of multinational companies, the national industry was forced to improve its efficiency to compete with new foreign companies, under the pressure of becoming gradually obsolete. Thus, this study aims to analyze the efficiency of the national and foreign companies that form the food and beverage sector in Brazil, post the productive reorganization.

It can be concluded that the efficiency of this industry is low, given that only a few firms have reached the maximum level of efficiency while the larger parcel of the sample had very unsatisfactory results. Such a conclusion is very disturbing, since the sector is one of the most expressive in the national transformation industry.

Differently from the hypothesis initially raised, i.e., that the foreign shareholding control would be a decisive factor for efficiency, it was observed that the companies with high levels of efficiency were those with the highest volume of sales. Out of the seven companies with sales volume greater than a billion dollars and with a maximum level of efficiency, three were national. Thus, efficiency was not determined only by the nationality of the firms, since the possibility of the accomplishment of profitable businesses, mainly in association with great retail networks, could be indicated as a determinant for greater efficiency. Nonetheless, it is worth emphasizing that the multinational firms may have advantages relating to sales, since they operate in different markets.

As for the determinants of efficiency, it was observed from the sample of firms studied here, that a proper financial administration, characterized by a good use of investments within these companies, was the main factor responsible for an improvement in performance. This conclusion was drawn from the 
strength in the marginal effect of the variable asset turnover, which is an indicator that refers to the number of times that the total asset of a company is transformed into money due to sales and corroborates the importance of the sales volume to the degree of efficiency.

In general, the results of the study are in accordance with qualitative analyses of the sector carried out by other authors. Nonetheless, some limitations must be emphasized: it is a very heterogeneous industry, in which some sub sectors are more developed than others, causing efficiency variations among the segments; there was a huge difficulty to achieve data from the companies, especially those related to the inputs.

For further studies, it would be advisable a more rigorous model for the determinants of efficiency, including other variables besides those relating to the financial gains of the companies.

\section{Bibliographical References}

Associação Brasileira das Indústrias de Alimentação (ABIA) (2007), Indústria da Alimentação - principais indicadores econômicos. São Paulo: http://www. abia.org.br/Ficha Técnica.pdf.

Assaf Neto, A. (2006), Estrutura e análise de balanços: um enfoque econômico-financeiro. 8 ed. São Paulo: Atlas.

Banker, R. D.; Charnes, A.; Cooper, W. W. (1984), 'Some models for estimating technical scale inefficiencies in Data Envelopment Analysis,' Management Science, 30 (9), 1078-1092.

Barreto, F. A. F. D.; Marinho, E.; Oliveira, V. H. (2006), 'Abertura econômica e desempenho da produtividade da indústria brasileira de 1985 a 1996: uma abordagem utilizando o índice de Malmquist e a teoria da fronteira estocástica,' in F. A. F. D. Barreto and V. H. Oliveira (eds), Produtividade: teoria e evidências para o Brasil e a América Latina. Edições UFC: Fortaleza, BR.

Bravo-Ureta, B. E.; Pinheiro, A. E. (1997), 'Technical economic and allocative efficiency in peasant farming: evidence from Dominican Republic,' The Developing Economics, 35 (1), 48-97.

Caves, R. E. (1992), Industrial efficiency in Six Nations. MIT Press: Cambridge, MA.

Charnes, A.; Cooper, W. W.; Rhodes, R. (1978), 'Measuring the efficiency of decision making units,' European Journal of Operational Research, 2 (6), 429-444.

Chilingerian, J. A. (1995), 'Evaluating physician efficiency in hospitals: a multivariate analysis of best practices,' European Journal of Operational Research, 80, 548-574.

Coelli, T.; Rao, D. S. P.; Battese, G. E. (1998), An introduction to efficiency and productivity analysis. Kluwer Academic: Norwell.

Cunha, D. A.; Dias; R. S. (2008), 'Indústria alimentícia brasileira: estrutura, conduta e 
desempenho pós-reestruturação empresarial - 1990 a 2000,' Revista Brasileira de Economia de Empresas, 8, 45-55.

Dong, F.; Feathersrone; A. (2006), 'Technical and scale efficiencies for Chinese rural credit cooperatives: a bootstrapping approach in Data Envelopment Analysis,' Journal of Chinese Economic and Business Studies, 4 (1), 57-75.

Efron, B.; Tibshirani; R. J. (1993), An introduction to the bootstrap. Chapman \& Hall: New York.

Farina, E. M. M. Q.; Nunes, R. (2004), 'Para além da agricultura: e efeito "treadmill” no sistema agroindustrial de alimentos no Brasil,' Economia Aplicada, 8 (2), 347-376.

Farina, E. M. M. Q.; Nunes, R. (2004), 'Supermarkets and their impacts on the agrifood system of Brazil: the competition among retailers,' Agribusiness - An International Journal, 21 (2), 133-146.

Farina, E. M. M. Q.; Viegas, C. A. S. (2005), 'Multinational Firms in the Brazilian Food Industry,'. in: R. Rama (ed), Multinational Agribusinesses. The Haworth Press.

Farreli, M. J. (1957), 'The measurement of productive efficiency,' Journal of Royal Statistical Society, 120 (2), 253-281.

Fethi, M. D.; Jackson, P. M.; Weyman-Jones, T. G. (2002), 'Measuring the efficiency of European airlines: An application of DEA and Tobit analysis,' Discussion Paper, University of Leicester.

Fundação Getúlio Vargas. (FGV) (2003), Impactos verticais da concentração do setor varejista brasileiro. São Paulo: FGV.

Greene, W.H. (1993), Econometric analysis. $2^{\text {nd }}$. ed. MacMillan: New York.

Instituto Brasileiro de Geografia e Estatística (IBGE) (2004), Pesquisa de orçamentos familiares 2002-2003: primeiros resultados, Brasil e grandes regiões. Coordenação de Índices de Preços. Rio de Janeiro: IBGE.

Hoff, A. (2007), 'Second stage DEA: Comparison of approaches for modelling the DEA score,' European Journal of Operational Research, 181, 425-435.

Jackson, P. M.; Fethi, M. D. (2000), 'Evaluating the technical efficiency of Turkish commercial banks: An Application of DEA and Tobit Analysis,' In: 21 INTERNATIONAL DEA SYMPOSIUM, University of Queensland, Brisbane, Australia.

Lothgren, M.; Tambour, M. (1999), 'Bootstrapping the Data Envelopment Analysis Malmquist Productivity Index,' Applied Economics, 31 (4), 417-425.

Macedo, M. A. S.; Souza, M. A. F. (2004), 'Avaliação de eficiência organizacional no setor de alimentos: uma contribuição à gestão industrial,’ http://simpep.feb. unesp.br/anais1o/gestãoestratégicaeorganizacional/arq14.pdf.

Mayes, D.; Harris, C.; Lansbury, M. (1994) Inefficiency in industry. Harvester Wheatsheaf.

Simar, L.; Wilson, P.W. (2002), 'Estimation and inference in two-stage, semi-parametric models of production processes,' Discussion Paper 0307, Institute de Statistique, Université Catholique de Louvain, Louvain-la-Neuve.

Souza, G. S.; Tabak, B. M. (2002), 'Factors affecting the technical efficiency of production of the Brazilian Banking System: A Comparison of four statistical models 
CUNHA, D.A.; SALAZAR, M.B. Efficiency of brazilian food and beverage......

in the context of DEA,' Working Paper, Banco Central do Brasil.

Tibshirani, R. (1996), 'Regression shrinkage and selection via the Lasso,' Journal of the Royal Statistical Society, 58 (1), 267-288.

Recebido em: 28 de agosto de 2012

Aceito em: 15 de janeiro de 2013 